\title{
Evaluation and Promotion of City Innovation Capability
}

\author{
XU Jun \\ Business School \\ Jiangsu Normal University \\ Xuzhou, China \\ lmmxjxj@163.com
}

\author{
REN Teng-fei \\ School of Business Administration \\ Henan Polytechnic University \\ Jiaozuo, China \\ rentengfei1993@163.com
}

\begin{abstract}
City innovation capability reflects the ability of a city to restructure and combine various resources. The purpose of evaluating city innovation capability is to enhance the comprehensive competitiveness of the city. First of all, this paper analyzes the present situation of city innovation capability from the aspects of policy system, innovation environment, innovation resources and industrial structure. Secondly, taking innovation investment, innovation environment and innovation output as research perspective, the evaluation index system of city innovation capability is constructed, as well as the coefficient of variation method and multi-index compositive evaluation method were adopted, the evaluation model of city innovation capability is established. Finally, from the analysis of current situation and the design of evaluation index system, the ways of promoting city innovation capability are designed from the aspects of government, industry and enterprise.
\end{abstract}

Keywords-City innovation capability; Status quo; Evaluation; Promotion

\section{INTRODUCTION}

City innovation capability, as an important branch of innovation theory, belongs to the category of regional innovation. The exploration of city innovation is the front issue of urban development, the academic research on city innovation capability mainly focuses on the following aspects: concept definition, construction of evaluation index system, evaluation model and method, path design, and so on. City innovation capability is the organic combination of each element, function mechanism and behavior entity in the city innovation system. The coordination and integration ability of all factors and innovation subjects in city innovation system is the comprehensive innovation ability of the city [1]. Promoting city innovation capability has important influence on radiation function. It not only can promote the system innovation, technological innovation and organizational innovation to enter a new stage of development, but also to achieve the accumulation of urban innovation energy.

\section{StATUS QUO OF City INNOVATION CAPABILITY}

\section{A. Innovation Investment Continues to Increase}

Promoting city innovation capability is an important step in the construction of an innovative country. The construction of innovation capability has been raised to the national strategic level, the government has constantly improved its investment mechanism and promoted the capitalization, industrialization and informatization of scientific and technological achievements [2]. As a whole, the R\&D expenditure of cities and regions in China has increased year by year, and the expenditure of R\&D funds has been on a steady upward trend. It shows that the internal expenditure growth rate of $R \& D$ expenditure exceeds the GDP growth rate. In particular, China spent 706.26 billion yuan on R\&D in 2010, just a quarter of 2015. As of 2015, China's R \& D spending has increased to 1416.99 billion yuan, accounting for $2.07 \%$ of GDP, the annual growth rate of more than $10 \%$. In particular, due to the weak foundation of innovation in our country, the proportion of national innovation investment has increased year by year, and the growth rate is large. Coupled with the cyclical characteristics of innovation, the innovation ability is difficult to achieve the immediate effect, so the innovation ability evaluation needs to pay more attention to the output effectiveness.

\section{B. Innovative Environment is Obviously Optimized}

There is a positive correlation between the speed of science and technology development and economic development in china. On the one hand, the investment in innovation is increasing. In 2015, the total number of $\mathrm{R} \& \mathrm{D}$ personnel in China was 3.759 million, an increase of $30.39 \%$ compared with 2011, in which basic research, applied research as well as the participants in pilot development study was $6.73 \%, 11.44 \%$, $81.83 \%$ respectively. Among the industrial enterprises above designated size, the proportion of enterprises with R\&D activities rose from $6.2 \%$ in 2004 to $19.2 \%$ in 2015 , while R\&D expenditure increased from 110.45 billion yuan to 1001.39 billion yuan [3].

On the other hand, innovation and output are increasingly abundant. In 2015, the number of scientific and technological achievements registered in China was 55284, the number of invention patents received was 1101900 , and the number of patents authorized for invention was 359300, and the authorized ratio was $32.61 \%$. The number of technology market transactions rose from 476.4 billion yuan in 2011 to 983.6 billion yuan in 2015, an average annual increase of 21.29 percent. From the basic situation of scientific and technological activities of industrial enterprises above designated size, in 2015 , the number of new product development projects was 
326286 , and the sales revenue of new products was 1.509 billion yuan.

\section{Innovative Resources are Becoming Increasingly Abundant}

In recent years, the factor environment of city innovation capability in China has been continuously improved. First of all the growth of talent resources is fast. In Yangzhou, for example, by the end of 2012, the total number of human resources in Yangzhou was 552.4 thousand, an increase of 102.4 thousand compared with 2010. Among them, there are 100.3 thousand enterprises, 259 thousand skilled professionals and 123.3 thousand high-tech talents. Secondly, the construction of innovative carrier platform in an orderly manner. Innovation carrier platform is the hardware environment of enterprise independent innovation. Taking Henan Province as an example, by the end of 2015, Henan had 1200 scientific research and technological development service institutions, including 90 provincial scientific research institutions, 115 institutions of higher learning institutions. Moreover, Henan has 38 provincial key laboratories, 6 state-level engineering research centers, 50 provincial-level engineering research centers, 2 state-level engineering research centers, and 23 provincial-level engineering research centers [4]. Finally, the difference of city innovation capability has been improved. There are significant regional differences in city innovation capacity in China. Overall, the western region is significantly lower than the central region and the eastern region, the northern region is lower than the southern region.

\section{Low Degree of Enterprise Concentration}

The structural contradictions caused by the imbalance of resource allocation are becoming an obstacle to enhance the city innovation ability. Firstly, the rapid development of hightech industries, but the proportion is low. In the period of 20112016, the growth rate of high-tech manufacturing in China showed a declining trend year by year, $16.5 \%, 12.2 \%, 11.8 \%$, $12.3 \%, 10.2 \%$ and $10.8 \%$ respectively. In 2016 , the added value of China's industrial strategic emerging industries grew by $10.5 \%$, and the added value of high-tech manufacturing industry accounted for $12.4 \%$ of the added value of industrial enterprises above designated size. Secondly, the proportion of the second industry is too high, and the problem of excess production capacity is prominent. In the period of 2012-2016, the proportion of China's second industry in the national economy is declining slowly, respectively, $45.3 \%, 44 \%, 43.1 \%$, $40.9 \%, 39.8 \%$, compares with the developed country, the progress space is very big. In 2012-2015, China's crude steel production capacity utilization rate was $72 \%, 74.9 \%, 74.8 \%$, $73.09 \%$, excess capacity accounted for a large number of production factors, leading to the structural contradictions of economy. Thirdly, the regional differences are obvious, industrial development is not balanced. China's eastern region has a higher level of economic development, city innovation capacity of the highest. According to Annual report of China's city innovation, the comprehensive score of Shanghai's innovation capability is 94.5034 points, ranking second in the Yangtze River Delta region. The city innovation capability of the central region is weaker than that of the eastern region, and the city innovation capability is the weakest in China's western region.

\section{EVALUATION OF CITY INNOVATION CAPABILITY}

\section{A. The Content of Evaluation Index System of City Innovation Capability}

This paper refers to Evaluation Index System of China's Innovative Cities, which is launched by China's innovative city evaluation program (2013). By referring to the latest research results in related fields, some important indexes are incorporated into the evaluation index system of city innovation capability [5]. This paper sets up three basic dimensions: innovation input, innovation environment and innovation output. In each basic dimension, six indicators of criterion layer, such as scientific and technological input, talent resources and innovation carrier, are set up respectively. Under the criterion layer, eighteen specific evaluation indicators are set. The evaluation index system of city innovation capability is shown in table I .

TABLE I. EVALUATION INDEX SYSTEM OF CITY INNOVATION CAPABILITY

\begin{tabular}{|c|c|c|}
\hline Target layer & Criterion layer & Index layer \\
\hline \multirow{6}{*}{$\begin{array}{l}\text { Innovation } \\
\text { investment }\end{array}$} & \multirow{3}{*}{$\begin{array}{c}\text { Scientific and } \\
\text { technological input }\end{array}$} & $\begin{array}{l}\text { R\&D investment in the whole } \\
\text { society accounted for GDP }\end{array}$ \\
\hline & & $\begin{array}{l}\text { Science and technology expenditure } \\
\text { accounts for local fiscal expenditure }\end{array}$ \\
\hline & & $\begin{array}{c}\text { Enterprise R\&D expenditure } \\
\text { accounts for product sales revenue }\end{array}$ \\
\hline & \multirow{3}{*}{ Talent resources } & $\begin{array}{l}\text { Professional and technical } \\
\text { personnel accounts for employees }\end{array}$ \\
\hline & & $\begin{array}{l}\text { College or higher population } \\
\text { account for population }\end{array}$ \\
\hline & & $\begin{array}{l}\text { Knowledge-intensive services } \\
\text { industry employment personnel } \\
\text { accounts for employees }\end{array}$ \\
\hline \multirow{6}{*}{$\begin{array}{l}\text { Innovation } \\
\text { environment }\end{array}$} & \multirow[b]{2}{*}{ Innovation carrier } & $\begin{array}{l}\text { Proportion of enterprises engaged } \\
\text { in innovative activities }\end{array}$ \\
\hline & & $\begin{array}{l}\text { Technical income of high-tech } \\
\text { industry development zone } \\
\text { accounts for total revenue }\end{array}$ \\
\hline & \multirow{4}{*}{$\begin{array}{l}\text { Economic and } \\
\text { social environment }\end{array}$} & GDP per capita \\
\hline & & Labor productivity \\
\hline & & $\begin{array}{c}\text { Enterprise research personnel } \\
\text { accounts for corporate employment }\end{array}$ \\
\hline & & $\begin{array}{c}\text { High-tech industry employment } \\
\text { personnel accounts for social } \\
\text { workers }\end{array}$ \\
\hline \multirow{6}{*}{$\begin{array}{l}\text { Innovation } \\
\text { output }\end{array}$} & \multirow{3}{*}{$\begin{array}{l}\text { Achievement } \\
\text { output }\end{array}$} & $\begin{array}{l}\text { Ownership of patented invention by } \\
\text { millions of people }\end{array}$ \\
\hline & & $\begin{array}{l}\text { Turnover of technical market by } \\
\text { millions of people }\end{array}$ \\
\hline & & $\begin{array}{c}\text { Ownership of well-known } \\
\text { trademarks by millions of people }\end{array}$ \\
\hline & \multirow{3}{*}{$\begin{array}{c}\text { Economic and } \\
\text { social development }\end{array}$} & $\begin{array}{l}\text { Export volume of high-tech product } \\
\text { accounts for total merchandise } \\
\text { exports }\end{array}$ \\
\hline & & $\begin{array}{l}\text { Labor productivity of high-tech } \\
\text { industry }\end{array}$ \\
\hline & & $\begin{array}{c}\text { Output value per unit } \\
\text { comprehensive energy consumption }\end{array}$ \\
\hline
\end{tabular}




\section{B. Calculation Steps of Comprehensive Evaluation Index of City Innovation Capability}

According to the needs of the empirical analysis of city innovation capability, this paper chooses the multi-index compositive evaluation method as an empirical research tool. The advantage of this method is that it is suitable for deeper analysis of the object of study. The procedures of multi-index comprehensive evaluation method include three parts: dimensionless index, index weight assignment and calculation comprehensive evaluation index.

1) Dimensionless evaluation index: In order to facilitate the unification of data, the data is processed with the dimensionless standardization. In this paper, extremum methods are used to standardize data.

The treatment formula of forward index:

$$
r_{i j}=\frac{x_{i j}-\min _{1 \leq i \leq m} x_{i j}}{\max _{1 \leq i \leq m} x_{i j}-\min _{1 \leq i \leq m} x_{i j}},(1 \leq i \leq m, 1 \leq j \leq n)
$$

The treatment formula of reverse index:

$$
r_{i j}=\frac{\max _{1 \leq i \leq m} X_{i j}-x_{i j}}{\max _{1 \leq i \leq m} X_{i j}-\min _{1 \leq i \leq m} X_{i j}},(1 \leq i \leq m, 1 \leq j \leq n)
$$

Among them, $r_{i j}$ is standardized data, $x_{i j}$ is the original data, $m$ is the city number, and $j$ is the index number.

2) Index weight assignment: Objective weighting reduces the interference of subjective factors, which is more reasonable than subjective weighting. In this paper, the index weight is determined by coefficient of variation method, and the specific steps are as follows.

Firstly, calculate the average $\left(\bar{x}_{j}\right)$ and standard deviation $\left(S_{j}\right)$ of each evaluation index.

$$
\begin{gathered}
\bar{x}_{j}=\frac{1}{n} \sum_{i=1}^{n} x_{i j}, j=1,2,3, \ldots, m \\
s_{j}=\sqrt{\frac{1}{n} \sum_{i=1}^{n}\left(x_{i j}-\bar{x}_{j}\right)^{2}}, j=1,2,3, \ldots, m
\end{gathered}
$$

Secondly, calculate the coefficient of variation $\left(K_{j}\right)$ of each evaluation index.

$$
K_{j}=\frac{s_{j}}{\bar{x}_{j}}, j=1,2,3, \ldots, m
$$

Thirdly, the coefficient of variation is normalized, and the corresponding weights $\left(W_{j}\right)$ of each index are obtained.

$$
W_{j}=\frac{K_{j}}{\sum_{j=1}^{m} K_{j}}, j=1,2,3, \ldots, m
$$

3) Calculation comprehensive evaluation index: By calculating the score of each index, the scores of each classification and the total score are obtained by the summation, and ranked according to the evaluation object score.

The formula is as follows:

$$
I=\sum_{i=1}^{n} W_{j} r_{i j}
$$

Among them, $W_{j}$ is the weight of each index, and $I$ is the index of city innovation capability or each component index.

\section{Countermeasures to Promote City InNOVAtion CAPABILITY}

\section{A. Enhance Government Management}

1) Improve government efficiency: The government is the leader of promoting city innovation capability, and the purpose of transforming government management function is to break the institutional barriers of independent innovation. Firstly, decentralization, and deal with the relationship between the markets. The government should deepen the reform of the administrative system, get rid of obstacles to the development of the industry, simplify procedures for approval, lower administrative costs, and stimulate the people's spirit of innovation and entrepreneurship. Secondly, promote the construction of service-oriented government, guide, and support and realize all kinds of innovations. The government has to change the way the government has led the industry, take the market regulation mechanism as the basis, follow the laws of the market, reduce administrative interference, and do a good job in the service enterprises and consumers.

2) Increase scientific and technological input: Scientific and technological input provides financial support for city innovation, and innovative talents provide intellectual support for urban innovation. First of all, support and encourage enterprises to increase investment in science and technology. The government should formulate tax relief policies, reduce the burden of small and medium-sized technology-based enterprises, and provide credit guarantee for enterprises with outstanding innovation capability, and ensure that the enterprises have enough innovative funds. Secondly, the establishment of diversified, multi-channel, high efficiency of science and technology investment system. The government 
should play the role of media and platform, make the bridge between technological enterprises and innovation factors, and use administrative resources to guide innovation factors to science and technology enterprises.

\section{B. Reliance on Industrial Power}

1) Reduce the proportion of traditional industries: Depending on the industry transformation and enterprise innovation, the city innovation ability can be improved by leaps and bounds. Firstly, promote the transformation and upgrading of traditional manufacturing. Relevant industries must upgrade the technological level of leading products, promote the transformation of parts and components to sophisticated direction, and change the low-end equipment manufacturing to large-scale, intelligent and environmental protection. Secondly, accelerate the development of strategic emerging industries. The competent authorities need to vigorously introduce and implement a number of major projects, extend the industrial chain, raise the level of industrial technology, promote the application of new industries in a wider field, and enlarge the driving role of demonstration projects.

2) Play the advantages of scientific research institutes: The enterprise is the main part of the innovation city construction, and the change of the enterprise production mode provides the impetus for the city innovation capability promotion [6]. First of all, guide enterprises to enhance the input consciousness of innovation. Enterprises should be encouraged to formulate long-term plans for scientific and technological innovation, and promote technological cooperation between enterprises and institutions of higher learning, scientific research institutions in the form of technology transfer, technology shares and joint development, so as to tap the potential of enterprise innovation. Secondly, strengthen the creation of intellectual property rights. Strengthen the construction of enterprise's own brand, encourage enterprises to apply for patent and strive for authorization, so as to form products with independent intellectual property rights. Finally, enhance the soft power of enterprises. Guide enterprises to establish and improve the modern enterprise system, improve the corporate governance structure, and vigorously promote the enterprise innovation culture.

\section{Strengthen the Innovation Support Force}

1) Build shared platform: The shared platform provides convenience for innovative information exchange accelerates the pace of urban innovation and promotes the industrialization of innovative results. Firstly, establish and improve the public service system of science and technology. The government should lead the construction of scientific and technological service sharing platform, increase the industrialization of scientific and technological innovation, and solve the problem of the close connection between science and technology and industry. Secondly, build a technology sharing information platform. Encourage enterprises to strengthen innovative information exchange, relying on technology sharing information platform to achieve resource sharing, protect enterprise intellectual property rights, prevent information leakage, causing property disputes.

2) Deepen the institutional innovation: Improving city innovation capability needs sound system guarantee. First, strengthen industry-university-research cooperation. Encourage research institute and universities to cooperate with enterprises, build a new mechanism for benefit sharing of production and research, and optimize the mechanism of enterprise technology transfer system. Second, improve the science and technology investment and financing system. Strengthen government guidance, build diversified financing mechanism, take social investment as the main source of innovation funds, seize the opportunity of government financial investment and tax incentives, and enlarge the government investment effect. Third, foster the intermediary service system of science and technology. The government should innovate management methods, foster various types of intermediary service agencies, encourage social forces to engage in scientific and technological intermediary services, enrich the content of services and improve the quality of service.

\section{CONCLUSION}

City innovation system is an important component of national innovation system. Promoting city innovation capability is a complex system engineering, which needs the support of government, industry, factors and so on. Based on the analysis of city innovation capability, the following conclusions are obtained: firstly, the city development stage and the innovation stage are not necessarily synchronous; secondly, the city innovation capability has a higher correlation with the city's comprehensive function; thirdly, the upgrading path of city innovation capability has diversified characteristics.

\section{REFERENCES}

[1] L Liu, Z L Yu, X H Xu,H Zhang, "Coupling coordination degree of city innovation capability and urbanization in Shandong province," Economic Geography, vol. 36, pp. 59-66, June 2016.(In Chinese)

[2] X Gao, "Urban sizes, human capital and innovative capacities of China cities," Journal of Social Sciences, pp. 49-58, March 2015. (In Chinese)

[3] Z T Deng and Q Y Tu, "Construction and application of megacities'innovation ability evaluation model," Science and Technology Management Research, pp. 52-55, June 2016. (In Chinese)

[4] E Lindhult, J Campillo, E Dahlquist, S Read, "Innovation capabilities and challenges for energy smart development in medium sized european cities," Energy Procedia, vol. 88, pp. 205-211, June 2016.

[5] A Abella, M Ortiz-de-Urbina-Criado, C De-Pablos-Heredero, "A model for the analysis of data-driven innovation and value generation in smart cities' ecosystems," Cities, vol. 64, pp. 47-53, April 2017.

[6] M Yi, L Gao, L S Yang, "A Study on spatio-temporal dynamic evolution law of innovation capacity in the urban agglomeration of the middle reaches of Yangtze river," Statistics \& Decision, pp. 134-138, May 2017. (In Chinese) 